\title{
Soil heating, nitrogen, cheatgrass, and seedbed microsites
}

\author{
ROBERT R. BLANK, LEAH ABRAHAM, AND JAMES A. YOUNG
}

Authors are soil scientist, research apprentice, and range scientist, respectively, USDA-ARS, Conservation Biology of Rangelands Unit, 920 Valley Road, Reno, Nev. 89512.

\begin{abstract}
Heat-induced changes in the soil-solution and post-wildfire erosion can create chemically and texturally diverse seedbed microsites. We quantified organic carbon, extractable $\mathrm{NH}_{4}+$ after incubation (aerobic and anaerobic), and emergence of cheatgrass (Bromus tectorum L.), by particle size fractions, in unburned and simulated burned sagebrush (Artemisia tridentata spp. tridentata Nutt.) subcanopy soil. For all particle size fractions, significantly $(P \leq 0.05)$ more extractable $\mathrm{NH}_{4}{ }^{+}$and significantly less extractable $\mathrm{NO}_{3}$ - were measured in heated material as compared to unheated material. Heated treatments had significantly more $\mathrm{NH}_{4}{ }^{+}$and significantly less $\mathrm{NO}_{3}$ - mineralized after 11 days aerobic incubation than after unheated treatments; net $\mathbf{N}$ mineralized tended to be higher for all particle fractions in heated treatments than in unheated treatments. Emergence of cheatgrass under aerobic conditions was significantly retarded in all heated treatments. Elevated $\mathrm{NH}_{4}+$ to $\mathrm{NO}_{3}$ - ratios in the soil-solution following heating does not explain suppression of cheatgrass emergence. Nitrogen mineralization, before and after simulated burning, is adequate in all particle size fractions to support the needs of germinating seeds. Nitrogen mineralization was not enhanced by the presence of growing cheatgrass plants.
\end{abstract}

Key Words: nitrate, ammonium, nitrogen mineralization, sagebrush

In sagebrush (Artemisia) plant communities in the Great Basin, water ultimately controls plant competition; however, $\mathrm{NO}_{3}{ }^{-}$and possibly $\mathrm{NH}_{4}{ }^{+}$in the seedbed soil-solution are the catalysts driving competition among seedlings for moisture. Considerable soluble $\mathrm{NO}_{3}{ }^{-}$can be lost from the soil following wildfires (White et al. 1973, Klemmedson 1976). Conversely, post-wildfire seedbeds often have elevated levels of $\mathrm{NH}_{4}{ }^{+}$(Christensen 1973, DeBano et al. 1979). Elevated levels of $\mathrm{NH}_{4}{ }^{+}$combined with depressed soil nitrification following wildfires (Dunn et al. 1985) leads to greater $\mathrm{NH}_{4}{ }^{+}$to $\mathrm{NO}_{3}{ }^{-}$ ratios than generally occur in the seedbed of sagebrush communities (Charley and West 1977). Increased uptake of $\mathrm{NH}_{4}{ }^{+}$relative to $\mathrm{NO}_{3}{ }^{-}$can be deleterious to newly establishing plants and may impact their competitive ability (Gigon and Rorison 1972, Marschner 1986).

Bare soil surfaces following wildfires are susceptible to increased movement of soil by wind and water that can lead to considerable loss of nitrogen (DeBano and Conrad 1978, Fletcher et al. 1978). On previously burned sagebrush landscapes in northeastern California and northwestern Nevada, the winnowing action of wind and water creates texturally variable deposits. Deposits range from fine-textured water-laid sediments to well-sorted fine and fine sand eolian deposits to coarse-textured lag deposits. These texturally diverse seedbeds, which may also vary in nitrogen status, could differentially influence the recruitment of plants (Harper et al. 1965, Collis-George and Hector 1966).

\footnotetext{
Authors wish to thank Ms. Debra Palmquist for assistance in statistical analyses, Ms. Fay Allen for laboratory work, and reviewers for their constructive comments. Manuscript accepted 17 Jul. 1993.
}

Our purpose was to:

a) quantify extractable $\mathrm{NO}_{3}{ }^{-}$and $\mathrm{NH}_{4}{ }^{+}$and nitrogen mineralization, before and after simulated burning, among particle size fractions separated from big sagebrush (Artemisia tridentata ssp. tridentata Nutt.) subcanoy soil;

b) determine if alteration of extractable $\mathrm{NH}_{4}{ }^{+}$to $\mathrm{NO}_{3}{ }^{-}$ratios, as a consequence of soil heating, influences the emergence of cheatgrass (Bromus tectorum L.) and;

c) determine the influence of cheatgrass growth on nitrogen mineralization before and after simulated burning.

\section{Materials and Methods}

\section{Soil Collection and Preparation}

The soil sampling area was from a sagebrush-grass plant community $30 \mathrm{~km}$ north of Reno, Nev. The soil is a fine-loamy, mixed, mesic, Durixerollic Haplargid and developed in granitic colluvium. Elevation is $1,555 \mathrm{~m}$ and average annual precipitation is 25 $\mathrm{cm}$. Soil was collected July 1992 from sagebrush subcanopies, 0 to $10 \mathrm{~cm}$, and included the litter layer. Three replicate samples were collected from areas approximately $100 \mathrm{~m}$ apart. From each area, soil was composited from 5 adjacent sagebrush subcanopies.

The 3 soil samples were each sieved through a $0.833 \mathrm{~mm}$ mesh and the $<0.833-\mathrm{mm}$ fraction was homogenized and saved. We chose to remove material larger than $0.833 \mathrm{~mm}$ because it was mostly undecomposed sagebrush litter. The $<0.833-\mathrm{mm}$ material was split; one-half was untreated, the other half artificially burned to simulate soil conditions following a wildfire. The heat treatment consisted of placing approximately $500 \mathrm{~g}$ of material in a ceramic crucible which was placed in a pre-heated $300^{\circ} \mathrm{C}$ muffle furnace for 15 minutes. Previous research has shown that this artificial treatment produces a soil-solution chemistry closely matching the immediate post-wildfire soil-solution chemistry beneath sagebrush subcanopies in similar soil (unpublished research, USDA-ARS, Reno, Nev.). Heated and unheated treatments were separated into the following size fractions using a stacked set of sieves and 10 minute shaking time on a mechanical shaker: $0.425-0.833 \mathrm{~mm}$, $0.300-0.425 \mathrm{~mm}, 0.180-0.300 \mathrm{~mm}$, and $<0.180 \mathrm{~mm}$. Another portion of each was left unsieved ( $<0.883 \mathrm{~mm}$ or whole fraction).

\section{Analytical}

The following attributes were determined on each size fraction of both heated and unheated treatments: organic carbon (WalkleyBlack method, Nelson and Sommers 1982); extractable $\mathrm{NH}_{4}{ }^{+}$and $\mathrm{NO}_{3}{ }^{-}$(10-g material shaken for 30 minutes with $30 \mathrm{ml}$ of $0.15 \%$ $\mathrm{KCl}, \mathrm{NH}_{4}{ }^{+}$determined by flow injection analysis, $\mathrm{NO}_{3}{ }^{-}$and $\mathrm{NO}_{2}{ }^{-}$ determined by ion chromatography); organic $\mathbf{N}$ (Kjeldahl method, Bremner and Mulvaney 1982); $\mathrm{pH}$ on a saturated paste.

Nitrogen mineralization was evaluated by aerobic and anaerobic methods (Keeney 1982). For both methods, 500-ml glass beakers were filled with $250 \mathrm{~g}$ of material. For the aerobic procedure, all materials were moistened with deionized water to $-0.033 \mathrm{MPa}$ as 
Table 1. Selected attributes of pre-incubated material from particle size fractions of heated and unheated big sagebrush subcanopy soil.

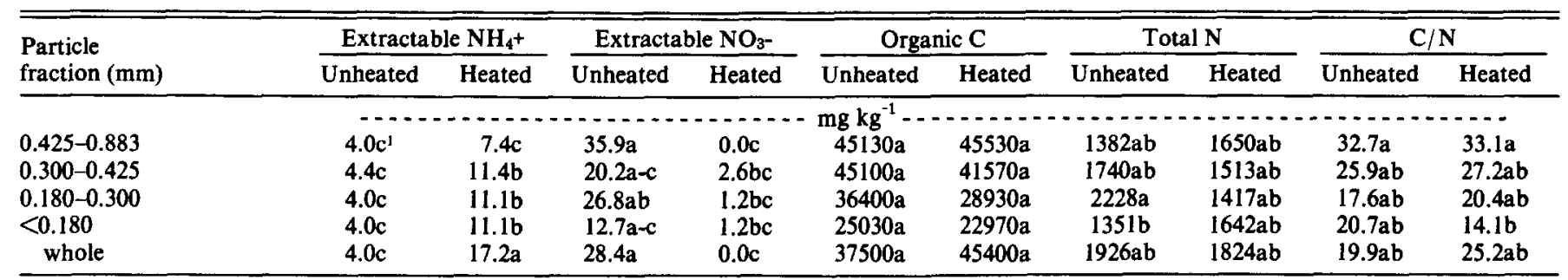

'Within soil attributes, particle fraction $\times$ heat treatment means followed by the same letter are not significantly different at the $P \leq 0.05$ level.

determined by a pressure plate membrane apparatus. To produce anaerobic conditions, water was added until it just completely covered the soil surface. Approximately $1 \mathrm{~g}$ of fresh soil was added to the heated treatment before incubation. This was necessary to re-introduce soil microorganisms killed during heating.

\section{Cheatgrass Emergence and N Mineralization Experiment}

To determine the influence of cheatgrass growth on $\mathrm{N}$ mineralization and the influence of simulated soil burning and cheatgrass emergence, seed treatments were superimposed on the mineralization treatments: minus seeds or plus seeds. The plus seed treatment consisted of 20 seeds of cheatgrass buried approximately $1 \mathrm{~cm}$. The seed was $>95 \%$ germinable as tested on moistened paper. Samples were incubated at $25^{\circ} \mathrm{C}$ under continuous fluorescent lighting for 11 days. Beakers were covered with parafilm, the anaerobic treatments sealed, the aerobic treatment loosely covered. At the end of the incubation period, the following parameters were measured: (a) emergence of cheatgrass; (b) organic carbon, extractable $\mathrm{NH}_{4}{ }^{+}$ and $\mathrm{NO}_{3}{ }^{-}$, and organic nitrogen as above; and (c) total nitrogen in emerged cheatgrass (leaves and roots) using an $\mathrm{H}_{2} \mathrm{O}_{2}$ modification of the Kjeldahl method (Isaac and Johnson 1976). Unemerged seeds were inspected to see if any had germinated; none had. Plant nitrogen was considered part of the mineralized pool.

\section{$\mathrm{NH}_{4}{ }^{+} / \mathrm{NO}_{3}{ }^{-}$Cheatgrass Germination Experiment}

To determine if elevated $\mathrm{NH}_{4}{ }^{+} / \mathrm{NO}_{3}{ }^{-}$ratios influence cheatgrass germination, post-heating levels were used as a guideline in a controlled experiment. Forty seeds of cheatgrass (4 replications) were placed on ashless filter paper in petri dishes and the following solutions (ug ml${ }^{-1}$ ) were added until the paper was saturated: 0 $\mathrm{NH}_{4}^{+}+0 \mathrm{NO}_{3}^{-}, 5 \mathrm{NH}_{4}^{+}+100 \mathrm{NO}_{3}^{-}, 100 \mathrm{NH}_{4}^{+}+0 \mathrm{NO}_{3}^{-}, 100 \mathrm{NH}_{4}^{+}+$ $100 \mathrm{NO}_{3}{ }^{-}, 400 \mathrm{NH}_{4}{ }^{+}+100 \mathrm{NO}_{3}{ }^{-}, 400 \mathrm{NH}_{4}{ }^{+}+0 \mathrm{NO}_{3}{ }^{-}$. Ammonium was added as $\mathrm{Cl}^{-}$salt and nitrate as $\mathrm{Na}^{+}$salt. Seeds were counted after 5 days and considered germinated if the radicle had emerged at least $1 \mathrm{~cm}$. The $\mathrm{pH}$ of the test solutions was similar for heated and unheated treatments (5.8-6.1), thus formation of $\mathrm{NH}_{3}$ was minimal.

\section{Statistics}

The experimental design was a completely random design with 3 replications. The preincubation data were analyzed using a 2-way analysis of variance with particle size and heat treatment as the 2 factors for each soil attribute. The postincubation data set used a 3-way analysis of variance with particle size, heat treatment, and incubation treatment as the 3 factors for each soil attribute. Duncan's new multiple range test was used for multiple comparisons. Significance was judged at the $P \leq 0.05$ level.

The germination experiment was a completely random design with 4 replications. Data were analyzed using a 1-way analysis of variance, where treatments consisted of selected combinations of $\mathrm{NH}_{4}^{+}$and $\mathrm{NO}_{3}{ }^{-}$solutions.

\section{Results and Discussion}

\section{Attributes of Pre-incubated Material}

Most particle fractions of the heated treatments contained significantly more extractable $\mathrm{NH}_{4}{ }^{+}$and less extractable $\mathrm{NO}_{3}{ }^{-}$than similar size fractions of unheated treatments (Table 1). The $300^{\circ} \mathrm{C}$ temperature in the simulated burning was higher than that reported to volatilize $\mathrm{NO}_{3}{ }^{-}$in soil (White et al. 1973, Raison 1979). Significantly elevated levels of $\mathrm{NH}_{4}{ }^{+}$after wildfires has been reported by others (Christensen 1973, Khanna and Raison 1986).

There were no significant differences in the amount of organic $\mathrm{C}$ between heated and unheated treatments (Table 1). This is surprising because the temperature of the simulated burn should have volatilized considerable organic C (Hosking 1938). Perhaps removal of plant litter by sieving before the simulated burn in part explains this finding.

Nitrogen content of particle size fractions varied considerably and was surprisingly high in the coarsest fractions (Table 1). For the unheated treatments, the $<0.180-\mathrm{mm}$ particle fraction contained the lowest $\mathbf{N}$ content of all size fractions and significantly less than the 0.180 to $0.300-\mathrm{mm}$ size fraction. However, there were no significant differences among the size classes for the heated treatments. Published literature shows variability in $\mathbf{N}$ content among particle size fractions. Nitrogen content tends to be lowest in sand fractions, increasing to a maximum in the fine silt fraction, and then decreasing somewhat in the clay fraction (Anderson et al. 1981, Catroux and Schnitzer 1987). Swift and Posner (1972) and Shiel (1986) reported $\mathbf{N}$ content decreased with an increase in fineness of particle size.

For individual particle fractions, there were no significant differences in $\mathbf{N}$ content between heated and unheated treatments (Table 1). This finding was not expected since $\mathrm{N}$ can be volatilized at the burn temperatures we used (DeBell and Ralston 1970, White et al. 1973). The length of simulated burning may have been insufficient to volatilize significant $\mathbf{N}$ or the nature of organic $\mathbf{N}$ in the soils tested may be recalcitrant to temperatures of $300^{\circ} \mathrm{C}$.

There were no significant differences in $\mathrm{C} / \mathrm{N}$ ratios between heated and unheated soils (Table 1). There was a trend toward decreasing $\mathrm{C} / \mathrm{N}$ ratios with decreasing particle size, which is supported by the findings of others (Shiel 1986, Catroux and Schnitzer 1987). The magnitude of $\mathrm{C} / \mathrm{N}$ ratios in the soils studied are much higher than generally reported for surface horizons of temperate agricultural soils (Stevenson 1959). As compared with other studies of sagebrush subcanopy soils, our $\mathrm{C} / \mathrm{N}$ ratios are higher than those of Burke (1989) and Bolton et al. (1990) and are considerably lower than those of Doescher et al. (1984).

\section{Changes in N Status Concomitant With Incubation}

There were no significant differences in any measured attribute between with or without seed treatments (see methods), therefore, these data are not presented. These findings address one of our objectives; $\mathrm{N}$ mineralization is not enhanced by the presence of cheatgrass plants that are growing. The plus and minus seed treat- 
Table 2. Net extractable $\mathrm{NH}_{4}+$ and $\mathrm{NO}_{3}$ - in particle size fractions of heated and unheated big sagebrush subcanopy soil after 11 days of aerobic and anaerobic incubation.

\begin{tabular}{|c|c|c|c|c|c|c|c|c|}
\hline \multirow{3}{*}{$\begin{array}{l}\text { Particle } \\
\text { fraction (mm) }\end{array}$} & \multicolumn{4}{|c|}{$\mathrm{NH}_{4}+$} & \multicolumn{4}{|c|}{$\mathrm{NO}_{3-}$} \\
\hline & \multicolumn{2}{|c|}{ Aerobic } & \multicolumn{2}{|c|}{ Anaerobic } & \multicolumn{2}{|c|}{ Aerobic } & \multicolumn{2}{|c|}{ Anaerobic } \\
\hline & Unheated & Heated & Unheated & Heated & Unheated & Heated & Unheated & Heated \\
\hline & \multicolumn{8}{|c|}{ 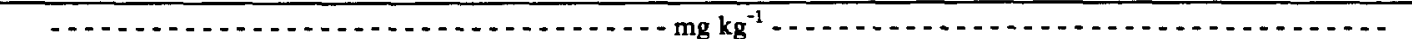 } \\
\hline $0.425-0.883$ & $11.9 \mathrm{i}^{1}$ & $66.1 \mathrm{a}$ & $61.8 \mathrm{ab}$ & $44.7 \mathrm{~d}-\mathrm{g}$ & $199.2 \mathrm{a}$ & $24.6 c-e$ & $-35.9 f$ & $0.0 \mathrm{c}-\mathrm{f}$ \\
\hline $0.300-0.425$ & $-1.9 \mathrm{i}$ & $60.5 a-c$ & $48.7 b-e$ & $37.2 \mathrm{e}-\mathrm{h}$ & 184.1ab & $42.8 \mathrm{c}$ & $-20.2 \mathrm{ef}$ & $-2.6 c-f$ \\
\hline $0.180-0.300$ & $-0.1 \mathrm{i}$ & $46.9 c-f$ & $35.8 \mathrm{e}-\mathrm{h}$ & $33.0 \mathrm{f}-\mathrm{h}$ & $144.8 \mathrm{~b}$ & $34.0 \mathrm{~cd}$ & $-26.8 f$ & $-1.2 c-f$ \\
\hline$<0.180$ & $0.2 \mathrm{i}$ & $49.8 \mathrm{~b}-\mathrm{e}$ & $43.5 \mathrm{~d}-\mathrm{h}$ & $30.3 \mathrm{~h}$ & $209.0 \mathrm{a}$ & $42.6 c$ & $-12.7 d-f$ & $-1.2 c-f$ \\
\hline whole & $3.6 \mathrm{i}$ & $52.5 \mathrm{a}-\mathrm{d}$ & $47.4 \mathrm{c}-\mathrm{e}$ & $31.8 \mathrm{gh}$ & $174.0 \mathrm{ab}$ & $40.1 \mathrm{c}$ & $-28.4 f$ & $0.0 \mathrm{c}-\mathrm{f}$ \\
\hline
\end{tabular}

'Within soil attributes, particle fraction $\times$ heat treatment $\times$ incubation treatment means followed by the same letter are not significantly different at the $P \leq 0.05$ level.

ments were pooled for subsequent statistical analyses (Table 2 and 3).

Significantly more $\mathrm{NH}_{4}{ }^{+}$was mineralized in heated treatments than the unheated control under aerobic incubation conditions, with coarse particle fractions in heated samples having significantly higher net mineralization of $\mathrm{NH}_{4}^{+}$than finer fractions (Table 2). Enhanced mineralization and release of $\mathrm{NH}_{4}{ }^{+}$following wildfires has been reported in different plant communities (Hobbs and Schimel 1984, Khanna and Raison 1986).

For heated treatments, significantly more $\mathrm{NH}_{4}{ }^{+}$was mineralized aerobically than anaerobically (Table 2). Since nitrification should be inhibited under anaerobic conditions, one would expect higher $\mathrm{NH}_{4}{ }^{+}$. Our findings suggest that either the rate of mineralization is slower under saturated conditions, perhaps due to decreased numbers of heterotrophic organisms in heated soils, and/or there is considerable denitrification under anaerobic incubations.

Under aerobic conditions, slightly less $\mathrm{NO}_{3}{ }^{-}$was mineralized in heated treatments than in unheated treatments (Table 2). Bell and Binkley (1989), using an aerobic procedure, reported a distinct trend toward lower levels of mineralized $\mathrm{NO}_{3}{ }^{-}$in heated soils than in unheated control soils. Given that considerable ammonification occurred in heated soils (Table 2), it appears that nitrification is slower in heated treatments. Nitrifying bacteria are especially susceptible to heat, whereas, ammonifiers can withstand heat because of thick cell walls or spore formation (Ahlgren and Ahlgren 1965, Raison 1979). Although we added fresh soil to the heated treatments to replace microorganisms killed by heat, the numbers may have been insufficient or the kinetics of microbial growth may have been too slow to rapidly convert $\mathrm{NH}_{4}^{+}$to $\mathrm{NO}_{3}{ }^{-}$.

Net total $\mathrm{N}$ mineralized under aerobic conditions was slightly greater for all particle sizes, in heated treatments compared to unheated treatments (Table 3). Percent $\mathrm{N}$ mineralized tended to decline with decreasing particle size for both heated and unheated treatments and aerobic and anaerobic incubation (Table 3). This is generally opposite of that reported in the literature (Chichester
1969, Catroux and Schnitzer 1987). In general, greater proportion of $\mathbf{N}$ was mineralized in heated soils than unheated soils.

\section{Cheatgrass Emergence}

In the aerobic environment, heated treatments consistently retarded cheatgrass emergence as compared to unheated treat-

Table 4. Percent emergence of cheatgrass from particle size fractions of heated and unheated big sagebrush subcanopy soil after 11 days aerobic and anaerobic incubation.

\begin{tabular}{lccccc}
\hline \hline \multirow{2}{*}{$\begin{array}{l}\text { Particle } \\
\text { fraction }(\mathrm{mm})\end{array}$} & \multicolumn{2}{c}{ Aerobic } & & \multicolumn{2}{c}{ Anaerobic } \\
\cline { 2 - 3 } \cline { 5 - 6 } \cline { 5 - 6 } & Unheated & Heated & & Unheated & Heated \\
\hline $0.425-0.833$ & $97.1 \mathrm{a}^{1}$ & $16.7 \mathrm{c}$ & & $1.7 \mathrm{c}$ & $5.0 \mathrm{c}$ \\
$0.300-0.425$ & $97.1 \mathrm{a}$ & $15.0 \mathrm{c}$ & & $3.3 \mathrm{c}$ & $3.3 \mathrm{c}$ \\
$0.180-0.300$ & $88.3 \mathrm{a}$ & $11.7 \mathrm{c}$ & & $0.0 \mathrm{c}$ & $8.3 \mathrm{c}$ \\
$<0.180$ & $90.0 \mathrm{a}$ & $46.7 \mathrm{~b}$ & & $3.3 \mathrm{c}$ & $3.3 \mathrm{c}$ \\
wholc & $95.0 \mathrm{a}$ & $8.3 \mathrm{c}$ & & $0.0 \mathrm{c}$ & $3.3 \mathrm{c}$ \\
\hline
\end{tabular}

IWithin soil attributes, particle fraction $X$ heat treatment $X$ incubation treatment means followed by the same letter are not significantly different at the $P \leq 0.05$ level.

ments (Table 4). For aerobic incubations, percent emergence was negatively correlated with the ratio of net mineralized $\mathrm{NH}_{4}^{+}$to net mineralized $\mathrm{NO}_{3}{ }^{-}$(Fig. 1).

Nitrate and $\mathrm{NH}_{4}{ }^{+}$can stimulate germination while excessive $\mathrm{NH}_{4}{ }^{+}$can inhibit germination of certain seeds (Hendricks and Taylorson 1974). Lack of $\mathrm{NO}_{3}{ }^{-}$or the excess of $\mathrm{NH}_{4}{ }^{+}$in heated soils did not contribute to depression of cheatgrass emergence for there were no significant differences in cheatgrass germination among the following test solutions in ug $\mathrm{ml}^{-1}$ (mean $\%$ germination): 0 $\mathrm{NH}_{4}^{+}, 0 \mathrm{NO}_{3}^{-}(85) ; 5 \mathrm{NH}_{4}^{+}, 100 \mathrm{NO}_{3}^{-}(91) ; 100 \mathrm{NH}_{4}^{+}, 0 \mathrm{NO}_{3}^{-}$(93); $100 \mathrm{NH}_{4}^{+}, 100 \mathrm{NO}_{3}^{-}(85) ; 400 \mathrm{NH}_{4}^{+}, 100 \mathrm{NO}_{3}^{-}(84) ; 400 \mathrm{NH}_{4}^{+}, 0$ $\mathrm{NO}_{3}^{-}(87)$.

Considerable quantities of organic acids can be produced by

Table 3. Net $\mathbf{N}$ mineralized and percent of total $\mathbf{N}$ mineralized in particle size fractions of heated and unheated big sagebrush subcanopy soil after 11 days of aerobic and anaerobic incubation. For treatments with emerging cheatgrass, total plant $\mathrm{N}$ was added to the mineralized and total $\mathrm{N}$-pool.

\begin{tabular}{|c|c|c|c|c|c|c|c|c|}
\hline \multirow{3}{*}{$\begin{array}{l}\text { Particle } \\
\text { fraction (mm) }\end{array}$} & \multicolumn{4}{|c|}{ Net mineralized $\mathbf{N}$} & \multicolumn{4}{|c|}{ Percent N mineralized } \\
\hline & \multicolumn{2}{|c|}{ Aerobic } & \multicolumn{2}{|c|}{ Anaerobic } & \multicolumn{2}{|c|}{ Aerobic } & \multicolumn{2}{|c|}{ Anaerobic } \\
\hline & Unheated & Heated & Unheated & Heated & Unheated & Heated & Unheated & Heated \\
\hline \multicolumn{9}{|c|}{$\ldots-\ldots \ldots \ldots-\ldots$ mg $^{1} \ldots \ldots \ldots$} \\
\hline $0.425-0.883$ & $56.1 \mathrm{ab} !$ & $57.8 \mathrm{a}$ & $40.0 c-g$ & $34.8 \mathrm{~d}-\mathrm{h}$ & $3.1 b c$ & $4.5 \mathrm{a}$ & $2.8 \mathrm{~b}-\mathrm{c}$ & $3.2 \mathrm{~b}$ \\
\hline $0.300-0.425$ & $41.8 \mathrm{~b}-\mathrm{f}$ & $57.2 \mathrm{a}$ & $33.3 \mathrm{e}-\mathrm{h}$ & $28.4 \mathrm{f}-\mathrm{h}$ & $2.2 \mathrm{~b}-\mathrm{g}$ & $3.2 \mathrm{~b}$ & $1.9 \mathrm{e}-\mathrm{g}$ & $2.0 \mathrm{~d}-\mathrm{g}$ \\
\hline $0.180-0.300$ & $35.4 \mathrm{~d}-\mathrm{h}$ & $44.9 \mathrm{a}-\mathrm{e}$ & $21.8 \mathrm{~h}$ & $25.4 \mathrm{gh}$ & $2.1 \mathrm{c}-\mathrm{g}$ & $3.0 \mathrm{~b}-\mathrm{d}$ & $1.3 \mathrm{~g}$ & $2.0 \mathrm{~d}-\mathrm{g}$ \\
\hline$<0.180$ & $48.9 a-d$ & $49.6 \mathrm{a}-\mathrm{d}$ & $31.0 \mathrm{e}-\mathrm{h}$ & $23.3 \mathrm{~h}$ & $1.6 \mathrm{fg}$ & $3.1 \mathrm{bc}$ & $1.8 \mathrm{e}-\mathrm{g}$ & $2.8 \mathrm{~b}-\mathrm{e}$ \\
\hline whole & $43.8 \mathrm{a}-\mathrm{c}$ & $50.4 a-c$ & $30.4 c-h$ & $24.7 \mathrm{~h}$ & $2.6 b-f$ & $3.2 \mathrm{~b}$ & $1.7 \mathrm{fg}$ & $1.7 \mathrm{fg}$ \\
\hline
\end{tabular}

'Within soil attributes, particle fraction $X$ heat treatment $X$ incubation treatment means followed by the same letter are not significantly different at the $P \leq 0.05$ leyel. 


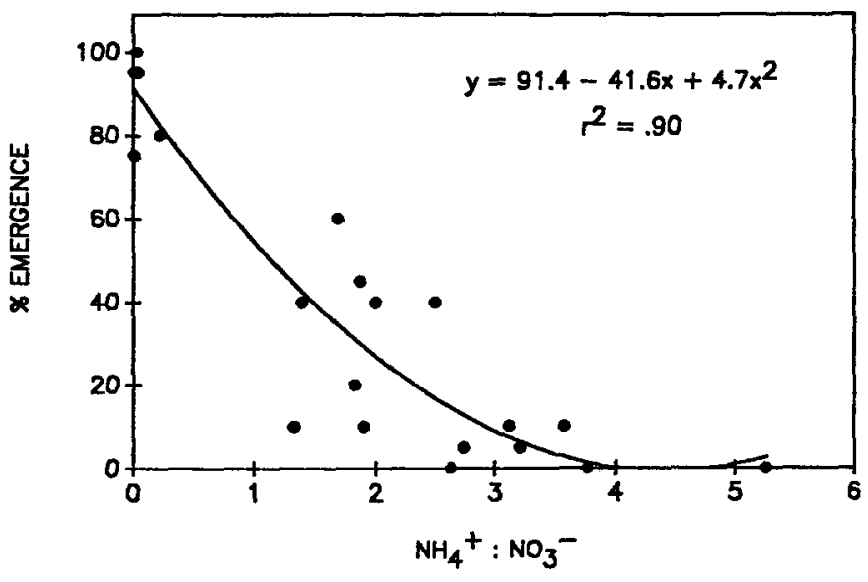

Fig. 1. Percent emergence of cheatgrass regressed against the ratio of net mineralized $\left(\mathrm{mg} \mathrm{kg}^{-1}\right) \mathrm{NO}_{3}^{-}$to $\mathrm{NH}_{4}^{+}$. Data are for aerobic incubations only.

heating sagebrush subcanopy soils (Blank and Young 1990). Organic acids at levels less than measured in the previous study have been shown to inhibit seed germination (Mayer and Evenari 1953, Adkins et al. 1985). Blank and Young (1990), however, reported no significant differences in the germination of needleand-thread grass (Stipa comata Trin. \& Rupr.), Indian ricegrass [Oryzopsis hymenoides (R. \& S.) Ricker], and cheatgrass between seeds grown in soil collected from sagebrush subcanopies following wildfire and a similar unburned control soil. The germintion trials, however, were conducted several weeks after the wildfire, at which time, compound(s) responsible for suppression of cheatgrass germination may have disappeared.

\section{Conclusions}

We suspected that seedbed microsites with varying soil textures caused by postwildfire soil erosion would differ in nitrogen fertility, and therefore, in their ability to function as safesites for germination. Our laboratory experiments, however, indicate that there is sufficient inorganic $\mathbf{N}$ and $\mathrm{N}$ mineralization capacity following simulated burning, even in medium sand-sized fractions, to supply the $\mathrm{N}$ needs of newly germinating seeds.

Artificially heated sagebrush subcanopy soils significantly depressed emergence of cheatgrass as compared to unheated controls. This finding is contrary to the observation of cheatgrass being an aggressive colonizer following wildfires (Stewart and Hull 1949). However, Young and Evans (1978) related that cheatgrass recruitment beneath sagebrush subcanopies was depressed the first year following a wildfire. They attributed this finding to caryopses loss due to intense heat. At this time we cannot offer a plausible mechanism, whereby heated soil retards the emergence of cheatgrass but are investigating the phenomenon further.

\section{Literature Cited}

Adkins, S.W., G.M. Simpson, and J.M. Naylor. 1985. The physiological basis of seed dormancy in Avena fatua. VII. Action of organic acids and pH. Physiol Plant. 65:310-316.

Ahlgren, I.F., and C.E. Ahlgren. 1965. Effects of prescribed burning on soil microorganisms in a Minnesota jack pine forest. Ecology 6:304-310
Anderson, D.W., S. Saggar, J.R. Bettany, and J.W.B. Stewart. 1981. Particle size fractions and their use in studies of soil organic matter: I. The nature and distribution of forms of carbon, nitrogen, and sulfur. Soil Sci. Amer. J. 45:767-772.

Bell, R.L., and D. Binkley. 1989. Soil nitrogen mineralization and immobilization in response to periodic prescribed fire in a loblolly pine plantation. Can. J. For. Res. 19:816-820.

Blank, R.R., and J.A. Young. 1990. Chemical changes in the soil induced by fire in a community dominated by shrub-grass. p. 256-259. In: Proc. Symp. on Cheatgrass Invasion, Shrub Die-off and other Aspects of Shrub Biology and Management. Las Vegas, Nev. USDA Forest Serv. Gen. Tech. Rep. INT-276. Ogden, Ut.

Bolton, H. Jr., J.L. Smith, and R.E. Wildung. 1990. Nitrogen mineralization potentials of shrub-steppe soils with different disturbance histories. Soil Sci. Soc. Amer. J. 54:887-891.

Bremner, J.M., and C.S. Mulvaney. 1982. Nitrogen-Total. p. 595-624. In: Methods of soil analysis-part 2. Amer. Soc. Agron, Madison, Wisc.

Burke, I.C. 1989. Control of nitrogen mineralization in a sagebrush steppe landscape. Ecology. 70:1115-1126.

Catroux, C., and M. Schnitzer. 1987. Chemical, spectroscopic, and biological characteristics of the organic matter in particle size fractions separated from an Aquoll. Soil Sci. Soc. Amer. J. 51:1200-1207.

Charley, J.L., and N.E. West. 1977. Micro-patterns of nitrogen mineralization activity in soils of some shrub-dominated semi-desert ecosystems of Utah. Soil Biol. Biochem. 9:357-365.

Chichester, F.W. 1969. Nitrogen in soil organic-mineral sedimentation fractions. Soil Sci. 107:356-363.

Christensen, N.L. 1973. Firc and the nitrogen cycle in California chaparral. Science 181:66-68.

Collis-George, N., and J.B. Hector. 1966. Germination of seeds as influenced by matric potential and by area of contact between seed and soil water. Aust. J. Soil Res. 4:145-164.

DeBano, L.F., and C.E. Conrad. 1978. The effect of fire on nutrients in a chaparral ecosystem. Ecology 59:489-497.

DeBano, L.F., G.E. Eberlein, and P.H. Dunn. 1979. Effect of burning on chaparral soils. I. Soil nitrogen. Soil Sci. Soc. Amer. J. 43:504-509.

DeBell, D.S., and C.W. Ralston. 1970. Release of nitrogen by burning light forest fuels. Soil Sci. Soc. Amer. Proc. 34:936-938.

Doescher, P.S., R.F. Miller, and A.H. Winward. 1984. Soil chemical patterns under eastern Oregon plant communities dominated by big sagebrush. Soil Sci. Soc. Amer. J. 48:659-663.

Dunn, P.H., S.C. Barro, and M. Poth. 1985. Soil moisture affects survival of microorganisms in heated chaparral soil. Soil Biol. Biochem. 17:143-148.

Fletcher, J.E., D.L. Sorensen, and D.B. Porcella. 1978. Erosional transfer of nitrogen in desert ecosystems. p. 171-181. In: N.E. West, and J. Skujins (eds.) Nitrogen in desert ecosystems. US/IBP synthesis series/9. Dowden, Hutchinson \& Ross, Inc., Stroudsburg, Penn.

Gigon, A., and I.H. Rorison. 1972. The response of some ecologically distinct plant species to nitrate-and to ammonium-nitrate. J. Ecol. 60:93-102

Harper, J.L., J.T. Williams, and G.R. Sager. 1965. The behavior of seeds in soils. Part $I$. The heterogeneity of soil surfaces and its role in determining the establishment of plants from seed. J. Ecol. 53:273-286.

Hendricks, S.B., and R.B. Taylorson. 1974. Promotion of seed germination by nitrate, nitrate, hydroxylamine, and ammonium salts. Plant Physiol. 54:304-309.

Hobbs, N.T., and D.S. Schimel. 1984. Fire effects on nitrogen mineralization and fixation in mountain shrub and grassland communities. $J$. Range Manage. 37:402-405.

Hosking, J.S. 1938. The ignition at low temperatures of the organic matter in soils. J. Agr. Sci. 28:393-400.

Isaac, R., and W. Johnson. 1976. Determination of total N in plant tissue using a block digestor. J. Assoc. Off. Anal. Chem. 59:

Keeney, D.R. 1982. Nitrogen-availability indices. p. 711-733. In: Methods of soil analysis - part 2. Amer. Soc. Agron., Madison, Wisc.

Khanna, P.K., and R.J. Raison. 1986. Effect of fire intensity on solution chemistry of surface soil under a Eucalyptus pauciflora forest. Aust. J. Soil Res. 24:423-434.

Klemmedson, J.O. 1976. Effect of thinning and slash burning on nitrogen and carbon in ecosystems of young dense ponderosa pine. For. Sci. 22:45-53.

Marschner, H. 1986. Mineral nutrition of higher plants. Academic Press, London.

Mayer, A.M., and M. Evenari. 1953. The activity of organic acids as germination inhibitors and its relation to $\mathrm{pH}$. J. Exper. Bot. 4:257-263. 
Nelson, D.W., and L.E. Sommers. 1982. Total carbon, organic carbon, and organic matter. p. 539-594. In: Methods of soil analysis-part 2. Amer. Soc. Agron., Madison, Wisc.

Raison, R.J. 1979. Modification of the soil environment by vegetation fires, with particular reference to nitrogen transformation: a review. Plant and Soil 51:73-108.

Shiel, R.S. 1986. Variation in amounts of carbon and nitrogen associated with particle size fractions of soils from the Palace Leas meadow hay plots. J. Soil Sci. 37:249-257.

Stevenson, F.J. 1959. Carbon-nitrogen relationships in soil. Soil Sci. 88:201-207.
Stewart, G., and A.C. Hull. 1949. Cheatgrass (Bromus tectorum L.)-an ecological intruder in southern Idaho. Ecology 30:58-74.

Swift, R.S., and A.M. Posner. 1972. The distribution and extraction of soil nitrogen as a function of soil particle size. Soil Biol. Biochem. 4:181-186.

White, E.M., W.W. Thompson, and F.R. Gartner. 1973. Heat effects on nutrient release from soils under ponderosa pine. J. Range Manage. 26:22-24.

Young, J.A., and R.A. Evans. 1978. Population dynamics after wildfires in sagebrush grasslands. J. Range Manage. 31:283-289.

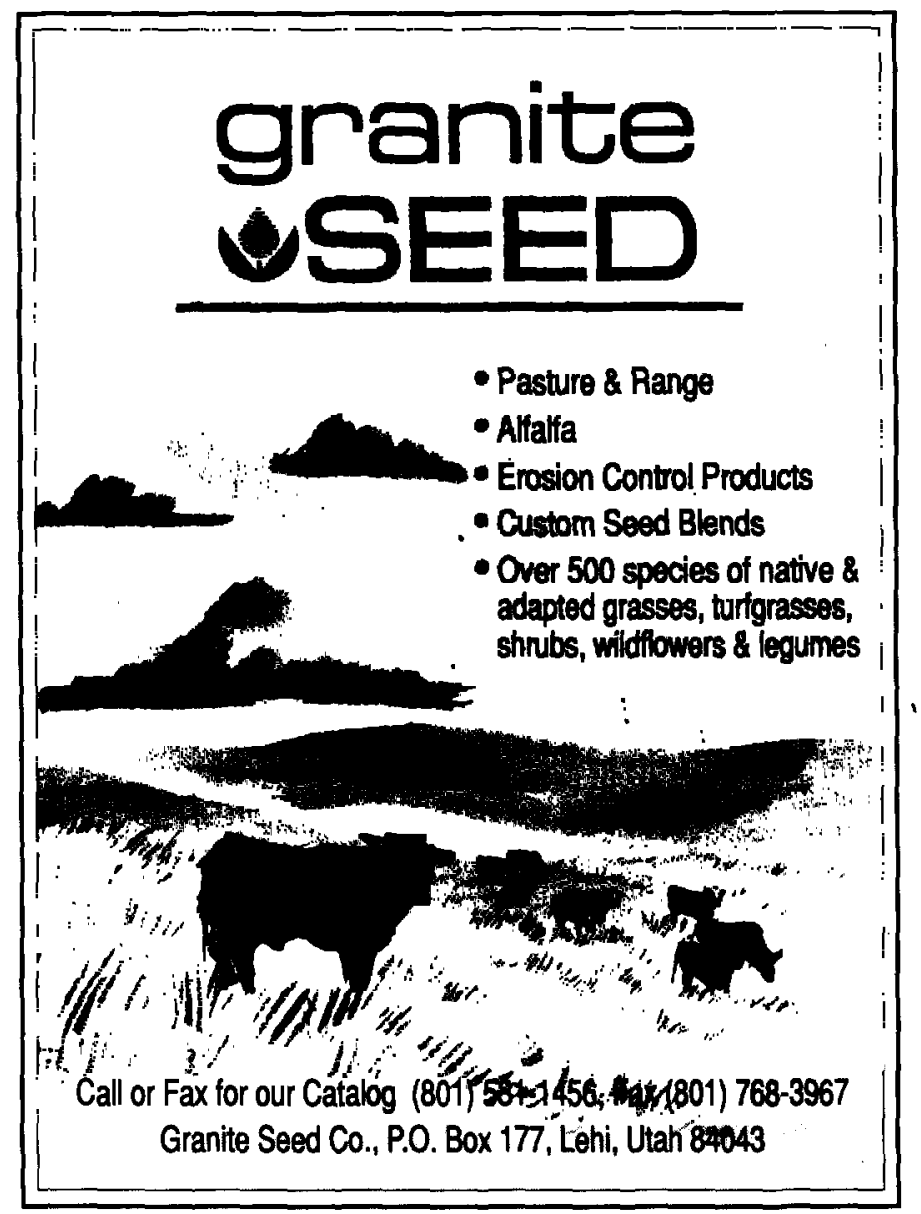

